\title{
A Study on the Korean-Version of the Youth Attitudes toward Noise Scale
}

\author{
Min Kyung Han ${ }^{a}$, Seonjin Kim ${ }^{\mathrm{b}}$ \\ ${ }^{a}$ Department of Communication Disorders, Indiana State University, Indiana, USA \\ ${ }^{b}$ Department of Statistics, Miami University, Ohio, USA
}

\author{
Correspondence: Min Kyung Han, PhD \\ Communication Disorders, Indiana State University, \\ 401 north 7th St., Terre Haute, Indiana 47809, USA \\ Tel: $+1-812-237-3780$ \\ Fax: +1-812-237-2729 \\ E-mail: min.han@indstate.edu
}

Received: July 5, 2020

Revised: July 27, 2020

Accepted: August 3, 2020

This research was supported by the Indiana Lions Speech and Hearing Project: McKinney Outreach Research Support awarded to Han
Objectives: The purpose of this study was to develop a Korean-version of the Youth Attitudes to Noise Scale (K-YANS) reflecting the primary causes of noise-induced hearing loss (NIHL): exposure to loud sounds in noisy places and unsafe listening practices on personal listening devices (PLDs). Methods: We translated the English-version of the YANS, which included 19 question items with four factors and selected four additional items relevant to youth's listening practices on PLDs. A total of 321 Korean college students completed an online survey on the K-YANS. We conducted confirmatory factor analysis, exploratory factor analysis, content validity measurement, and Pearson's correlation coefficient to measure the validity of the items; and Cronbach's alpha coefficient to measure the reliability. Additionally, we conducted multiple linear regressions to examine the effects of age and gender on attitudes toward noise. Results: A series of factor analyses led to the final version of the K-YANS of 16 items with three factors. The content validity of the items was 87 . All three factors had a positive linear relationship with the entire YANS with Factor 1 having the highest Pearson's correlation coefficient (.78). Cronbach's alpha coefficient for all 16 items was .73. The results of multiple linear regressions showed a significant effect of gender but not a significant effect of age on attitudes toward noise. Conclusion: The K-YANS is a valid and reliable self-report measure that can be used to assess NIHL and promote safe listening practices in young adults.

Keywords: Youth Attitudes to Noise Scale (YANS), Noise-induced hearing loss (NIHL), Personal listening devices (PLDs)
Communicative participation is the ability to communicate in everyday life activities and is necessary to fulfil daily life roles in vocational, social, and home settings (Baylor et al., 2013). A communicative participation restriction is an important assessment area in aural rehabilitation plans. High noise may be one of the causes of communicative participation restrictions especially in young adults. The World Health Organization (WHO) pointed out two causes of noise-induced hearing loss (NIHL) for young adults: (a) exposure to high levels of sound in noisy entertainment places and (b) unsafe listening practices with personal listening devices (PLDs). These two causes are associated with the fact that 1.1 billion young people worldwide are at risk of developing hear- ing loss (WHO, 2015). Approximately $40-50 \%$ of young adults in many countries are exposed to high levels of sound in noisy places such as clubs, concerts, festivals, and sports events and listen to unsafe levels of sounds when using PLDs such as iPods and MP3 players (WHO, 2015).

NIHL causes are explained by intensity more than exposure time and distance from a sound source. The National Institute on Deafness and Other Communication Disorders (NIDCD, 2019) states that sounds at or below $70 \mathrm{dBA}$, for any time period, are safe listening sounds, whereas long or repeated exposure to sounds at or above $85 \mathrm{dBA}$ can cause hearing loss. Sounds from normal conversation occur at 60-70 dBA whereas sounds in noisy entertain- 
ment places and from PLDs are excessively high. For example, night clubs at 80-106 dBA, Jazz concerts at 77-100 dBA, Rock/pop concerts at 80-120 dBA, live shows at $85 \mathrm{dBA}$, and sporting events at 94-114 dBA (Berger, Neitzel, \& Kladden, 2015). Sounds from PLDs can reach up to $121 \mathrm{dBA}$ at the highest volume control settings (Fligor \& Cox, 2004). Thus, young adults are exposed to very high levels of sound, damaging their hearing and negatively affecting physical, psychological, and emotional health, as well as communication.

High levels of sound affect hearing. The healthy hair cells in the cochlea of the inner ear are responsible for chemical changes, resulting in electric charges inside the cells. These changes make electrochemical impulses which travel along the auditory nerve to the brain that interprets the impulses as sound. However, high levels of sound damage the hair cells, generating a series of chemical events, and eventually resulting in cell death. In addition, intense bursts of sound can rupture the tympanic membrane and break the ossicular chain in the middle ear and generate temporary threshold shift (NIDCD, 2019). NIHL often accompanies hearing symptoms such as tinnitus. Tinnitus can be caused by long-duration noise, explosion, or brief intense noise (Henry, Dennis, \& Schechter, 2005).

High levels of sound affect psychological or mental health. Noise can disturb sleep, daily activity performance, and concentration. Noise increases stress and annoyance, which may cause cardiovascular disease (e.g., van Kempen et al., 2002). Additionally, hearing loss can cause social isolation and depression (Centers for Disease Control and Prevention [CDC], 2018).

High levels of sound affect communication. The signs and symptoms associated with NIHL are as follows: muffled speech and other sounds; difficulty hearing high-pitched sounds; difficulty understanding conversations in a noisy place; difficulty understanding phone conversations; trouble in speech discrimination; asking others to speak slowly, clearly, loudly, and repeatedly; and increasing the volume of the television or radio (CDC, 2018). A word learning study by Han, Storkel, Lee, and Cox (2016) revealed that word learning by young adults requires multiple cues of word characteristics to facilitate word learning in noisy learning environments compared to quiet environments.

Although noise greatly impacts hearing, psychological and emotional health, speech, language, communication, and learning; there is no medical or surgical treatment for NIHL because damaged hair cells cannot be restored (Hong, Kerr, Poling, \& Dhar, 2013). However, NIHL is considered preventable (NIDCD, 2019). To prevent NIHL, it is critical to understand what attitudes toward noise and hearing protection young adults have, which may change and/or influence preventive strategies and programs. "Not all individuals exposed to a given noise level develop the same degree of hearing loss," (Hong et al., 2013, p. 110) implying individual differences not only in anatomical and physiological conditions but also in susceptibility among people being exposed. Thus, subjective self-report measures for NIHL should be implemented as a part of the assessments for aural rehabilitation.

The Youth Attitudes to Noise Scale (YANS) is a self-report measure used to examine youth' attitudes toward noise. The YANS was developed originally in Sweden by Widén and Erlandsson (2004) and has been translated and modified for adolescents and college students in the U.S.A. (Widén, Holmes, \& Erlandsson, 2006), Brazil (Zocoli, Morata, \& Marques, 2009), China (Zhu et al., 2014), and Belgium (Degeest, Maes, Leyssens, \& Keppler, 2018). The YANS consists of 19 question items and the items are categorized into four factors: Factor 1 regarding attitudes toward noise associated with youth culture; Factor 2 regarding attitudes toward the ability to concentrate in noisy situations; Factor 3 regarding attitudes toward daily noises; and Factor 4 regarding attitudes toward influencing the sound environment. A 5-point Likert scale is used ranging from "strongly agree (coded as 5)" to "strongly disagree (coded as 1)." When a person's total response values are placed in a lower quartile, the person is considered having a negative attitude toward noise (i.e., he/she perceives noise as something harmful). When a person's total response values are placed in the two middle quartiles, the person is considered having a neutral attitude toward noise (i.e., he/she is indifferent to noise and related problems). When a person's total response values are placed in an upper quartile, the person is considered having a positive attitude toward noise (i.e., he/she perceives noise as something non-problematic).

Many of the question items in the YANS are relevant to exposure to high levels of sound in noisy entertainment places. However, the YANS does not reflect a potential risk of hearing loss due to 
unsafe listening practices for PLDs. The purpose of this study was to develop a Korean-version YANS (K-YANS) by adapting the English-version YANS and by adding new items regarding the use of PLDs. The K-YANS can be used (a) to evaluate young adults' attitudes toward noise and (b) to educate young adults about hearing loss preventive strategies and programs. To develop the K-YANS, we translated between Korean and English and measured the validity and reliability of the K-YANS. In addition, we explored the effects of age and gender on young adults' perception of loud noise that they experienced.

\section{METHODS}

\section{Translation process and validity measurement}

The 19 items English-version YANS was translated into Korean by the first author. Four new items regarding the use of earphones or headphones associated with PLDs in our daily life (See below for details) were selected from Portnuff (2016). The four items were also translated into Korean by the first author. A Korean otolaryngologist confirmed that the terminologies and phrases in the 23 items were accurate and appropriate in Korean contexts. Following that, two Korean speech-language pathologists compared the two versions and examined if the Korean version used grammatical sentences and delivered the same meaning as the English version.

To elicit common, shared meaning from respondents and to increase the validity of the questionnaire, three processes took place. First, 11 speech-language pathologists, none of whom were involved in the translation process, 11 Korean college students, none of whom participated in the current YANS survey, and eight Korean middle and high school teachers took part in an online survey on the clarity of the question items. If they encountered difficulties in understanding and answering a question, they were asked to make comments on the reasons for the difficulties. The items were revised according to their comments. Second, a Korean speech-language pathologist who is proficient in spoken and written English conducted a counter-translation: translating the Korean version into an English one. The result of the counter-transition verified negligible differences in the meaning of each item between the two versions. Lastly, five Korean otolaryngologists par- ticipated in an online survey on how the question items adequately measure the content area of noise with a 5-point Likert scale ( $5=$ strongly agree, $4=$ somewhat agree, $3=$ neither agree nor disagree, $2=$ somewhat disagree, and $1=$ strongly disagree).

\section{Recruitment}

We used two strategies to recruit participants: the snowball and convenient sampling methods. We included in the survey flyer a sentence implying the snowball sampling method (i.e., "We are looking for a large number of responses, so please feel free to forward this research link to any undergraduate and graduate students you know of" "본 연구의 특성상 많은 응답자가 필요합니다. 본 설문조사 사이트 링크를 주위의 대학생들에게 알려 조사에 응 할 수 있게 해주시면 감사하겠습니다.”). Regarding the convenient sampling method, we asked a small number of college students who were available and willing to participate. In addition, we asked the parents and relatives of potential participants, and professors to forward the survey flyer to college students.

\section{Participants}

Participants took part in this study anonymously. A total of 321 college students (mean age $=21.56, \mathrm{SD}=2.79$, range $=18-30$; $\mathrm{N}_{\text {male }}=67, \mathrm{~N}_{\text {female }}=250, \mathrm{~N}_{\text {other }}=1, \mathrm{~N}_{\text {no response }}=3$ ) fully completed the survey. The participants were all native speakers of Korean from different universities across South Korea. They reported no problems with speech, language, hearing, physical, and medical development. There was no compensation for their participation in this survey. The study protocol was approved for exempt status by the institutional review board. The survey was delivered to participants through Qualtrics, an online survey platform.

\section{Survey}

The survey was designed to develop a K-YANS by adding four new items relevant to PLDs to the existing English-version YANS. For the purpose of this study, the survey was comprised of four sections: (a) informed consent, (b) demographic information, (c) hearing symptom description, and (d) the K-YANS. The K-YANS includes four factors, with 19 items from the English version and four newly added items regarding PLDs, resulting in a total of 23 items. The newly added items were: Item 5 "I think it is dangerous 
to wear earphones or headphones while driving a car or riding a bike (운전을 하거나 자전거를 탈 때 이어폰이나 헤드폰을 착용하 는 것은 위험하다고 생각한다.)"; Item 10 "I think that earphones/ headphones may damage hearing when they are used for a long time in noisy environments (소음이 심한 곳에서 음악 감상 등을 위해 이어폰이나 헤드폰을 오래 사용하면 청력이 손상될 수 있다 고 나는 생각한다.)"; Item 12 "I think that earphones/headphones may impede conversation (이어폰이나 헤드폰 착용한 채 대화를 하면, 정상적인 의사소통에 방해가 될 수 있다고 나는 생각한다.)”; and Item 23 "I think that earphones/headphones can mask auditory warning signals, such as sounds of traffic on a busy street (이 어폰이나 헤드폰을 착용한 상태로 길을 걸으면, 신호등이나 차량 의 이동 소리를 못 들을 수 있다고 나는 생각한다.)” A 5-point Likert scale was used ranging from "strongly agree (coded as 5)" to “strongly disagree (coded as 1)." Items 1, 4, 5, 10, 12, 15, 22, and 23 were coded inversely as they were in the English-version YANS. In addition, an inverse coding was also applied to Item 13 due to a translation issue between the two languages. That is, "strongly agree" was coded as 1, "somewhat agree" as 2, "neither agree nor disagree" as 3, "somewhat disagree" as 4, and "strongly disagree" as 5 .

\section{RESULTS}

The data were analyzed using statistical software R.

\section{Validity}

Confirmatory factor analysis was performed first to assess whether the K-YANS consisted of the same factors as the ones in the English-version YANS. It was found that the four factors in the K-YANS did not correspond well with those in the English-version YANS. Furthermore, Factor 1, Factor 2, and Factor 3 explained the variation more substantially than Factor 4. This incompatibility in the factors between the K-YANS and the English-version YANS led the authors to decide to include only three factors in the KYANS instead of four factors. With these three factors, two processes were taken. First, exploratory factor analysis was performed to determine which items were important and represent a factor. Based on the results of exploratory factor analysis, seven items whose factorial loadings were less than .4 in an absolute value, a rule of thumb, were excluded from the K-YANS. They are Items 2, $3,8,9,16,18$, and 21. Second, exploratory factor analysis was performed with the remaining 16 items to assign them to each of the three factors and identify shared characteristics of the items in a given factor. As seen in Table 1, results revealed that Factor 1 consisted of Items $1,4,7,11$, and 15, which was characterized by attitudes toward noise associated with youth culture; Factor 2 consisted of Items $6,14,17,19,20$, and 22, which was characterized by attitudes toward the ability to concentrate in noisy situations; and Factor 3 consisted of Items 5, 10, 12, 13, and 23, which was characterized by attitudes toward the use of PLDs. Accordingly, new numbers were assigned to the 16 items for the final K-YANS. Appendix presents the factors, items, characteristics, and descriptions for the original and final K-YANS.

The content validity of the final K-YANS measured by five Korean otolaryngologists was $4.34 / 5.00(.87)$ on average $[4.36 / 5.00$ (.87) for Factor 1; 4.30/5.00 (.86) for Factor 2; and 4.44/5.00 (.89) for Factor 3], suggesting high validity of the K-YANS. Pearson's correlation coefficient was performed to evaluate the linear correlation among the factors and the entire YANS (Table 2). All three factors have a positive linear relationship with the entire YANS. In particular, Factor 1 has the strongest linear association with the entire YANS among the three factors.

Table 1. Exploratory factor analysis

\begin{tabular}{lccc}
\hline & \multicolumn{3}{c}{ Factorial loadings } \\
\cline { 2 - 4 } Item \# & Factor 1 & Factor 2 & Factor 3 \\
\hline 11 & 0.71 & & \\
15 & 0.66 & & \\
1 & 0.64 & & \\
7 & 0.57 & & \\
4 & 0.55 & & \\
14 & & 0.62 & \\
20 & & 0.62 & \\
17 & & 0.50 & \\
6 & & 0.44 & \\
19 & & 0.40 & \\
22 & & 0.37 & 0.56 \\
13 & & & 0.54 \\
12 & & & 0.54 \\
23 & & & 0.38 \\
10 & & & 0.36 \\
5 & & & \\
Explained variation (\%) & 13.1 & & \\
\hline
\end{tabular}




\section{Reliability}

Cronbach's alpha coefficient was performed to evaluate how consistently related the items are in a given factor. As seen in Table 2 , results demonstrated the highest consistency between the items in Factor 1 (.78), followed by Factor 2 (.67) and Factor 3 (.59) with the lowest. The alpha coefficient for all 16 items was .73, which suggests that the items have acceptable internal consistency regardless of the fact that not all factors reached .70. Note that a reliability coefficient of .70 or higher is considered acceptable (Lance, Butts, \& Michels, 2006).

\section{The Effects of age and gender}

Multiple linear regressions of the K-YANS scores on age, gender and the interaction between age and gender were conducted to explore whether these factors have an influence on attitudes toward noise. Results as seen in Table 3 showed a significant effect of gender on attitudes toward noise ( $p=.01$, but not the effect of age ( $p=.75)$. Since there was no age effect, the two-sample t-test was performed to evaluate the marginal gender effect on attitudes toward noise. The results of the two-sample $t$-test $\left[t_{(315)}=2.83, p=.005\right]$ demonstrated that male students $(\mathrm{M}=44.45, \mathrm{SD}=6.44)$ scored 2.56 points greater on average than female students $(\mathrm{M}=41.89, \mathrm{SD}=6.60)$. This implies that male students tend to have more positive attitudes toward noise (i.e., noise is something unproblematic) than female students do.

\section{DISCUSSION \& CONCLUSION}

This study was designed to develop a K-YANS that reflects the two primary causes of NIHL in young adults: exposure to loud sound from noisy places and the use of PLDs. Unlike other language versions of four factors that mostly reflect only one cause

Table 2. Cronbach's alpha and Pearson's correlation between the factors and entire YANS

\begin{tabular}{lcccc}
\hline & Factor 1 & Factor 2 & Factor 3 & Entire YANS \\
\hline Factor 1 & - & .32 & .18 & .78 \\
Factor 2 & .32 & - & .05 & .73 \\
Factor 3 & .18 & .05 & - & .49 \\
Entire YANS & .78 & .73 & .49 & - \\
Cronbach's Alpha & .78 & .67 & .59 & .73 \\
\hline
\end{tabular}

YANS = Youth Attitude to Noise Scale. (i.e., exposure to loud sound from noisy places) of NIHL, the KYANS consists of three factors that reflect both causes of NIHL. These three factors are relevant to the attitudes toward noise associated with youth culture (Factor 1), attitudes toward the ability to concentrate in noisy situations (Factor 2); and attitudes toward the use of PLDs (Factor 3). The content validity of the K-YANS was high and all three factors have a strong relationship with the total YANS. High internal reliability within the items was also found. Additionally, there was no effect of age on the participants' scores of the K-YANS but an effect of gender was found with higher YANS scores in male students, indicating that male students tend to perceive noise as less problematic than female students do.

The effects of noise should be discussed not only from objective results obtained from medical and audiological examinations or experimental research, but also from subjective results from selfreport questionnaires including the YANS in order to obtain comprehensive assessment and establish specific (re)habilitation plans for NIHL. Due to individual differences in how noise is perceived, individuals exposed to a given noise level do not all have the same degree of hearing loss (Hong et al., 2013). Regardless of similar results from objective results from audiological examinations, different hearing acuity among individuals can be explained by subjective results on individuals' perception of noise, hearing symptoms, and noise protections. Individual's attitudes toward noise can provide information on what noise protection strategies are necessary for the individual, eventually preventing NIHL.

This study found the importance of socio-cultural contexts in examining young adults' attitudes toward noise. The item assignments to the factors of the YANS vary from country to country because individuals' attitudes toward noise are influenced by individuals' socio-cultural environments. The K-YANS is remarkably different from other versions. First, the K-YANS includes items relevant to young adults' use of PLDs in an attempt to reflect the fact that hearing loss is significantly attributed to unsafe listening

Table 3. Multiple linear regressions of the K-YANS for age and gender

\begin{tabular}{lrrcc}
\hline & Estimate & SD & $t$-value & $p$-value \\
\hline Intercept & 43.54 & 2.97 & 14.65 & $<2 \mathrm{e}-16$ \\
Age & .04 & .13 & .32 & .75 \\
Gender & -2.55 & .91 & -2.81 & .01 \\
\hline
\end{tabular}

$\mathrm{SD}=$ Standard deviation. 
practices while young adults are wearing earphones/headphones to listen with PLDs. Second, several items were excluded from the K-YANS that did not fit in any of the factors, which did not occur in the Swedish, English, Portugal, Chinese, and Dutch versions. Third, the K-YANS is comprised of three factors instead of four factors in other language versions. Factor 1 in the K-YANS seems to be a subset of Factor 1 in the English-version YANS. Thus, it can be considered that Factor 1 in the K-YANS is made up with key items in Factor 1 from the English-version YANS. This strongly reflects youth's attitudes toward noise in noisy settings. Interestingly, most of the items in Factor 2 are transferred from Factor 3 in the English-version YANS and characterized by concentration skills in various noisy environments. Importantly, all four newly added items regarding the use of PLDs are categorized into one factor, Factor 3, which makes our justification for this study strong. Taken together, an individual's attitudes toward noise should be considered within the context in which the person lives.

This study found the highest correlation between Factor 1 (regarding attitudes towards noise associated with youth culture) and the entire K-YANS, and the highest internal consistency in Factor 1. This is consistent with the findings in other language versions. This indicates that all language versions of the YANS can best reflect cultural aspects of perceived noise in young adults. Compared to other age groups, young adults engage more in activities in noisy places in which they are exposed to excessively high levels of sound (Widén \& Erlandsson, 2004), suggesting a high worldwide prevalence of NIHL in young adults (WHO, 2015). Factor 1 can be used to evaluate how young adults perceive noise due to the activities they engage in.

This study found no effect of age on young adults' attitudes toward noise but did find a significant effect of gender. No effect of age may be attributed to the concentration of students on the age range from 18 to 24 with a median of 21 . The students may have similar attitudes toward noise. Regarding the gender effect, a significant effect of gender was also found in the English- and Chinese-version YANS (Widén et al., 2006, and Zhu et al., 2014, respectively). However, the direction of the attitudes was different from one another. The K-YANS and the English-version YANS found that female students perceived noise more negatively than male students do, indicating more noise sensitivity in females than males. In contrast, the Chinese-version YANS found that female students perceived noise more positively than male students do, indicating higher noise sensitivity in males than females. For this study, the data obtained from the demographic information, hearing symptom description, and the K-YANS are limited in explaining the gender effect even with these inconsistent results. Thus, the effect of gender on youths' attitudes toward noise needs to be investigated more thoroughly to find the underlying variables of the gender difference.

Studies based on the two theories of risk-tasking behaviors can shed light on clinical implications of the K-YANS to assess youth's hearing loss and develop preventive strategies and programs: the health belief model and the theory of planned behavior. According to the studies based on the health belief model (Rosenstock, 1974), individuals' perception of noise and noise related hearing problems can trigger preventative actions. Individuals who self-reported hearing symptoms, including hearing loss, had more negative attitudes toward noise (i.e., noise or hearing loss is considered problematic) and used hearing protection devices more than those who self-reported no hearing problems (Bogoch, House, \& Kudla, 2005; Keppler, Dhooge, \& Vinck, 2015; Rawool \& ColligonWayne, 2008; Widén, Homes, Johnson, Bohlin, \& Erlandsson, 2009).

According to the studies based on the theory of planned behavior (Ajzen, 1991), individuals' intention to perform a certain behavior is determined by underlying factors including attitudes toward the behavior, subjective norms, and perceived behavioral control. Which factors have a significant correlation with intention vary depending on a behavior. Studies on attitudes toward noise, hearing loss, and hearing protection devices found that attitude is a strong predictor of the use of hearing protection (e.g., Balanay \& Kearney, 2015). In addition, attitudes about listening behaviors were more associated with an intention to reduce unsafe listening behaviors rather than social norms (Gopal, Champlin, \& Phillips, 2019).

These theories and findings support the importance of the use of K-YANS, a self-report questionnaire, as a part of the assessments in aural (re)habilitation. The K-YANS will provide insights into young adults' attitudes toward noise, their sound environments, possible exposure to loud noise, and their listening practic- 
es when using PLDs. These theories and findings also support the importance of the education of the effects of noise on individuals' health and life, which will help them be aware of the negative effects of noise and avoid the risks of NIHL by using appropriate hearing protective devices and following safe listening practices.

One issue is that this study used the data collected only from college students aged 18-30. To fully understand youth's attitudes toward noise, future research needs to include data from adolescents. The effect of age was found in adolescents aged 13-19 in Widén and Erlandsson (2004) in which older students reported more frequent visits to noisy places and a higher prevalence of noise related problems than younger students. Although our study did not find any age effect on college students' attitudes toward noise, it is interesting to investigate whether Korean students' attitudes toward noise change over time and what factors have interactions with age, which will provide important insights on aural rehabilitation strategies and programs as well as health and education policies.

\section{REFERENCES}

Ajzen, I. (1991). The theory of planned behavior. Organizational Behavior and Human Decision Processes, 50(2), 179-211.

Balanay, J. A. G., \& Kearney, G. D. (2015). Attitudes toward noise, perceived hearing symptoms, and reported use of hearing protection among college students: influence of youth culture. Noise \& Health, 17(79), 394-405.

Baylor, C., Yorkston, K., Eadie, T., Kim, J., Chung, H., \& Amtmann, D. (2013). The Communicative Participation Item Bank (CPIB): item bank calibration and development of a disorder-generic short form. Journal of Speech, Language, and Hearing Research, 56(4), 1190-1208.

Berger, E. H., Neitzel, R., \& Kladden, C. A. (2015). Noise Navigator ${ }^{T M}$ Sound Level Database, Version 1.8. Indianapolis, Available at: http://multimedia.3m. $\mathrm{com} / \mathrm{mws} /$ media/888553O/noise-navigator-sound-levelhearing-protection database.pdf.

Bogoch, I., House, R. A., \& Kudla, I. (2005). Perceptions about hearing protection and noise-induced hearing loss of attendees of rock concerts. $\mathrm{Ca}$ nadian Journal of Public Health, 96(1), 69-72.

Centers for Disease Control and Prevention. (2018). Loud noise can cause hearing loss. Available at: https://www.cdc.gov/nceh/hearing_loss/how_ do_i_know_if_i_have_hearing_loss.html
Degeest, S., Maes, L., Leyssens, L., \& Keppler, H. (2018). The test-retest reliability of questionnaires regarding attitudes and beliefs toward noise, hearing loss, and hearing protector devices in young adults. Noise \& Health, 20(93), 31-36.

Fligor, B. J., \& Cox, L. C. (2004). Output levels of commercially available portable compact disc players and the potential risk to hearing. Ear and Hearing, 25(6), 513-527.

Gopal, K. V., Champlin, S., \& Phillips, B. (2019). Assessment of safe listening intentional behavior toward personal listening devices in young adults. International Journal of Environmental Research and Public Health, 16(17), 3180-3190.

Han, M. K., Storkel, H. L., Lee, J., \& Cox, C. (2016). The effects of phonotactic probability and neighborhood density on adults' word learning in noisy conditions. American Journal of Speech-Language Pathology, 25(4), 547560.

Henry, J. A., Dennis, K. C., \& Schechter, M. A. (2005). General review of tinnitus: prevalence, mechanisms, effects, and management. Journal of Speech, Language, and Hearing Research, 48(5), 1204-1235.

Hong, O., Kerr, M. J., Poling, G. L., \& Dhar, S. (2013). Understanding and preventing noise-induced hearing loss. Disease-a-Month, 59(4), 110-118.

Keppler, H., Dhooge, I., \& Vinck, B. (2015). Hearing in young adults. Part I: the effects of attitudes and beliefs toward noise, hearing loss, and hearing protector devices. Noise \& Hearing, 17(78), 237-244.

Lance, C. E., Butts, M. M., \& Michels, L. C. (2006). The sources of four commonly reported cutoff criteria: what did they really say? Organizational Research Methods, 9(2), 202-220.

National Institute on Deafness and Other Communicate Disorders. (2019). Noise-induced hearing loss. Available at: https:/www.who.int/deafness/ make-listening-safe/standard-for-safe-listening/en/.

Portnuff, C. D. F. (2016). Reducing the risk of music-induced hearing loss from overuse of portable listening devices: understanding the problems and establishing strategies for improving awareness in adolescents. Adolescent Health, Medicine and Therapeutics, 7, 27-35.

Rawool, V. W., \& Colligon-Wayne, L. A. (2008). Auditory lifestyles and beliefs related to hearing loss among college students in the USA. Noise and Health, 10(38), 1-10.

Rosenstock, I. M. (1974). The Health Belief Model and preventive health, behavior. Health Education Monographs, 2(4), 354-386.

Van Kempen, E. E. M. M., Kruize, H., Boshuizen, H. C., Ameling, C. B., Staatsen, B. A. M., \& de Hollander, A. E. M. (2002). The association between 
noise exposure and blood pressure and ischemic heart disease: a metaanalysis. Environmental Health Perspectives, 110(3), 307-317.

Widén, S. E., \& Erlandsson, S. I. (2004). Self-reported tinnitus and noise sensitivity among adolescents in Sweden. Noise \& Health, 7(25), 29-40.

Widén, S. E., Holmes, A. E., \& Erlandsson, S. I. (2006). Reported hearing protection use in young adults from Sweden and the USA: effects of attitude and gender. International Journal of Audiology, 45(5), 273-280.

Widén, S. E., Holmes, A. E., Johnson, T., Bohlin, M., \& Erlandsson, S. I. (2009). Hearing, use of hearing protection and attitudes towards noise among young American adults. International Journal of Audiology, 48(8),
537-545.

World Health Organization. (2015). World hearing day 2015: Make listening safe. Available at: https://www.who.int/news-room/events/detail/2015/03/03/default-calendar/world-hearing-day-2015-make-listening-safe.

Zocoli, A. M., Morata, T. C., \& Marques, J. M. (2009). Youth attitude to noise scale (YANS) questionnaire adaptation into Brazilian Portuguese. Brazilian Journal of Otorhinolaryngology, 75(4), 485-492.

Zhu, X., Bihi, A., Hu, X., Lv, Y., Abbas, A., Zhu, X., Mo, L., \& Peng, X. (2014). Chinese-adapted youth attitude to noise scale: evaluation of validity and reliability. Noise \& Health, 16(71), 218-222. 
Appendix 1. Factors, item numbers, characteristics, and descriptions for the original and final K-YANS

\begin{tabular}{|c|c|c|c|c|c|}
\hline $\begin{array}{l}\text { Original } \\
\text { factor }\end{array}$ & $\begin{array}{l}\text { Original } \\
\text { item \# }\end{array}$ & $\begin{array}{l}\text { Final } \\
\text { factor }\end{array}$ & $\begin{array}{l}\text { Final } \\
\text { item \# }\end{array}$ & $\begin{array}{c}\text { Final } \\
\text { characteristic }\end{array}$ & Description \\
\hline F1 & 1 & F1 & 1 & Youth Culture & 나는 일반적으로 클럽, 콘서트, 축제, 스포츠 행사에서 발생하는 소리가 지나치게 크다고 생각한다. \\
\hline F1 & 4 & $\mathrm{~F} 1$ & 3 & & 클럽, 콘서트, 축제, 스포츠 행사에서 발생하는 소리가 너무 크면, 나는 그 장소를 나올 수도 있다. \\
\hline F1 & 7 & F1 & 6 & & 내가 클럽, 콘서트, 축제, 스포츠 행사에 갔을 때, 귀마개를 사용할 필요가 없다고 생각한다. \\
\hline F1 & 11 & $\mathrm{~F} 1$ & 8 & & 클럽, 콘서트, 축제, 스포츠 행사에서 발생하는 소리를 시끄러운 소음으로 생각하지 않는다. \\
\hline F1 & 15 & F1 & 12 & & 클럽, 콘서트, 축제, 스포츠 행사에서 발생하는 소리의 크기를 줄여야 한다. \\
\hline F2 & 6 & F2 & 5 & Concentration & 주위에서 여러 소리가 들리더라도 나는 집중할 수 있다. \\
\hline F3 & 14 & $\mathrm{~F} 2$ & 11 & & 자동차의 소음이 내 일이나 공부를 방해하지 않는다. \\
\hline F3 & 17 & $\mathrm{~F} 2$ & 14 & & 환풍기, 냉장고, 컴퓨터 등에서 나는 소리가 내 일이나 공부를 방해하지 않는다. \\
\hline F3 & 19 & $\mathrm{~F} 2$ & 2 & & 내가 다니는 학교 안의 소음은 적당한 편이다. \\
\hline F3 & 20 & $\mathrm{~F} 2$ & 15 & & 나는 자동차나 도로에서 들리는 소리에 민감하지 않다. \\
\hline F4 & 22 & $\mathrm{~F} 2$ & 13 & & 신경 쓰이는 소리를 없애지 못했을 때, 나는 무력감을 느낀다. \\
\hline \multirow[t]{5}{*}{ F1 } & 13 & F3 & 10 & PLDs & 소음과 큰 소리는 우리 사회에서 흔하게 경험하는 것이다. \\
\hline & 5 & F3 & 4 & & 운전을 하거나 자전거를 탈 때 이어폰이나 헤드폰을 착용하는 것은 위험하다고 생각한다. \\
\hline & 10 & F3 & 7 & & $\begin{array}{l}\text { 소음이 심한 곳에서 음악 감상 등을 위해 이어폰이나 헤드폰을 오래 사용하면 청력이 손상될 수 } \\
\text { 있다고 나는 생각한다. }\end{array}$ \\
\hline & 12 & F3 & 9 & & 이어폰이나 헤드폰 착용한 채 대화를 하면, 정상적인 의사소통에 방해가 될 수 있다고 나는 생각한다. \\
\hline & 23 & F3 & 16 & & $\begin{array}{l}\text { 이어폰이나 헤드폰을 착용한 상태로 길을 걸으면, 신호등이나 차량의 이동 소리를 못 들을 수 있다고 } \\
\text { 나는 생각한다. }\end{array}$ \\
\hline
\end{tabular}

All item numbers stated in this study refer to the original item numbers assigned to the original K-YANS.

Since Items 5, 10, 12, and 23 were newly added to the K-YANS, they were not assigned to the original factors that were adopted from the English-version YANS.

An inverse coding was applied to the items whose description is in italic.

The following items were excluded from the K-YANS after a series of factor analyses.

F2 Item 2: 숙제를 할 때 음악을 들으면 집중이 잘 된다.

F4 Item 3: 나는 좀 더 조용한 학교 환경을 조성하기 위해 어떤 일이든 할 수 있다.

F2 Item 8: 내 자신이 시끄러운 소음을 만들지 않는 것이 중요하다고 나는 생각한다.

F1 Item 9: 내 주위가 조용한 것이 나는 싫다.

F3 Item 16: 교실은 소란하지 않고 조용한 곳이어야 한다고 생각한다.

F1 Item 18: 나는 어떤 활동을 하다 주변의 소음이 지나치게 커지면, 그 활동을 멈출 것이다.

PLD=Personal Listening Device. 


\section{국문초록}

\section{한국어용 소음에 대한 청(소)년의 태도측정 검사도구(K-YANS) 개발 연구}

한민경 $\cdot$ 김선진

${ }^{1}$ 인디애나주립대학교 언어치료학과, ${ }^{2}$ 마이애미대학교 통계학과

배경 및 목적: 소음이 발생하는 환경에 노출되고 개인용 청취장치를 안전하게 사용하지 않는 관행이 소음성 청각장애의 주된 두 원인 으로 알려져 있다. 본 연구에서 저자들은 이를 반영하는 한국어용 소음에 대한 청(소)년의 태도측정 검사도구(K-YANS)를 개발하고자 하였다. 방법: 저자들은 19 개 문항, 4 개의 요인으로 구성된 영어 YANS를 번역하였고, 여기에 개인용 청취장치 사용과 관련된 문항 네 개를 추가하여 23 개 문항을 만들었다. 23 개 문항의 타당도를 높이기 위해, 언어치료사, 이비인후과 의사, 교사들이 참여한 설문조사 결 과를 바탕으로 문항을 수정한 후, 한국 대학생 321명을 대상으로 K-YANS 온라인 설문조사를 실시하였다. 타당도 검사를 위해, 확인요 인분석, 탐색요인분석, 내용타당도 검사를 실시하였고 피어슨상관계수를 구하였다. 신뢰도 검사를 위해, 크론바흐알파계수를 구하였 다. 또한, 연령과 성별에 따라 소음을 대하는 학생들의 태도가 변화하는지 다중선형회귀분석을 통하여 살펴보았다. 결과: 일련의 요인 분석 결과에 따라, 최종 K-YANS에 16 문항 세 개의 요인이 들어가게 되었다. K-YANS의 타당도는 .87이었고, 세 요인 모두 전체 YANS과 양적 선형관계를 이루고 요인 1 의 피어슨상관계수가 .78로 가장 높았다. 크론바흐알파계수는 .73이었으며, 다중선형회귀분석 결과, 소 음에 대한 태도가 연령에 따라 차이가 없었지만 성별에 따라서는 차이가 있었다. 논의 및 결론: K-YANS는 국내 청년에게 적용하였을 때 타당도와 신뢰도가 높은 자기보고 검사도구로서, 이들의 소음성 장애를 평가하고 안전한 청취 관행을 고취시키는 데 사용될 수 있 을 것이다.

핵심어: 소음에 대한 청(소)년의 태도측정 검사도구, 소음성 청각장애, 개인용 청취도구

본 연구는 미국 인디애나라이온즈클럽 언어청각프로젝트: 맥키니 연구기금 지원을 받아수행되었음.

\section{ORCID}

한민경(제1저자, 교신저자, 교수 https://orcid. org/0000-0002-9501-8187); 김선진(공동저자, 교수 https://orcid.org/0000-0001-6058-0420) 